\title{
Ligand-induced downregulation of receptors for TGF- $\beta$ in human osteoblast-like cells from adult donors
}

\author{
J Gebken ${ }^{3}$, A Feydt ${ }^{3}$, J Brinckmann' ${ }^{2}$, H Notbohm ${ }^{3}$, P K Müller ${ }^{3}$ \\ and B Bätge ${ }^{1}$ \\ ${ }^{1}$ Medizinische Klinik I, Medizinische Universität zu Lübeck, Ratzeburger Alle 160, D-23538 Lübeck, Germany \\ ${ }^{2}$ Klinik für Dermatologie, Medizinische Universität zu Lübeck, Ratzeburger Alle 160, D-23538 Lübeck, Germany \\ ${ }^{3}$ Institut für Medizinische Molekularbiologie, Medizinische Universität zu Lübeck, Ratzeburger Alle 160, D-23538 Lübeck, Germany \\ (Requests for offprints should be addressed to B Bätge)
}

\begin{abstract}
High concentrations of transforming growth factor $b$ (TGF- $\beta$ ) are found in the bone matrix, reflecting a pivotal role of this growth factor in the coupling of bone resorption and formation. TGF- $\beta$ strongly stimulates the synthesis of extracellular matrix proteins, but in vitro studies show an inhibitory effect on the final mineralization process, which in vivo occurs despite high concentrations of TGF- $\beta$. Little is known about how bone-forming cells respond to different concentrations of TGF- $\beta$ and if they can transiently adapt receptor numbers in order to modulate cellular activity. Against this background, we studied the cell-surface expression of TGF- $\beta$ receptors (T $\beta$ R) I, II and III (betaglycan) on human osteoblast-like cells from adult donors, and examined the T $\beta R$ presentation on these cells after a preceding exposure to TGF- $\beta 1$. Affinity crosslinking studies with disuccinimidylsuberate showed the presence of all three receptor types. Preincubation with TGF- $\beta 1$ markedly reduced ${ }^{125}$ I-TGF- $\beta 1$ binding in a time-dependent and dose-dependent manner and
\end{abstract}

revealed a 95\% reduction after an 18 -h preincubation with 200 pM TGF- $\beta 1$. In parallel, Scatchard analysis showed that the binding affinity did not change as a consequence of TGF- $\beta 1$ preincubation. Immunoblotting analyses revealed an almost complete disappearance of immunoreactive T $\beta R$-II and T $\beta R$-III proteins after a $24-h$ preincubation with TGF- $\beta 1$. Using semi-quantitative reverse transcription PCR, no effect of TGF- $\beta 1$ on the expression of T $\beta R-I I$ mRNA was observed. These studies demonstrate a ligand-induced downregulation of T $\beta$ Rs-II and -III on human osteoblast-like cells, without any evidence for recovery within the first $24 \mathrm{~h}$, both in the presence and after the removal of the ligand. The underlying mechanism appears to be based on post-transcriptional events. The results suggest that high concentrations of active TGF- $\beta 1$ decrease the responsiveness of osteoblasts towards this growth factor.

Journal of Endocrinology (1999) 161, 503-510

\section{Introduction}

Transforming growth factors $\beta$ (TGF- $\beta$ s), together with insulin-like growth factors I and II, are the most abundant growth factors stored in bone and known to function as potent regulators of osteoblast proliferation and differentiation and of production of extracellular matrix proteins (Bonewald \& Dallos 1994, Centrella et al. 1994). In particular, these factors exert a strong influence on the quantity and quality of collagen synthesized by human osteoblasts in vitro (Centrella et al. 1992, Seitzer et al. 1995). The biological effects of TGF- $\beta$ are mediated by TGF- $\beta$ receptors types I and II (T $\beta$ R-I and -II), which form a hetero-oligomeric signalling complex (Yamashita et al. 1994). Whereas both these receptors, but not betaglycan (T $\beta \mathrm{R}-\mathrm{III}$ ), are required for inducing signal transduction, only T $\beta \mathrm{R}-\mathrm{II}$ can bind the ligand even in the absence of T $\beta \mathrm{R}-\mathrm{I}$, but not vice versa (Franzén et al. 1993).
As TGF- $\beta$ has been shown to prevent the development of differentiated phenotypes - for example those associated with mineralization - changing biological effects of TGF- $\beta$ in different stages of tissue formation are of central importance (Wrana et al. 1988, Noda 1989, Harris et al. 1994). TGF- $\beta$ is secreted by bone cells and stored in the bone matrix in a latent form, ready to be activated and inactivated at key, pivotal stages in the process of bone formation (Bonewald \& Dallas 1994). There is recent experimental evidence that activated TGF- $\beta$ can be extracted in substantial concentrations from the bone matrix (Pfeilschifter et al. 1998). However, little is known about how the responsiveness of osteoblasts towards active TGF- $\beta$ present in the osteoblastic microenvironment might be regulated in humans, although adaptive changes of the responsiveness might represent further control mechanisms once TGF- $\beta$ is activated. Changing biological effects of TGF- $\beta$ as a result of altered receptor binding 
under the influence of certain growth factors have been demonstrated by in vitro studies using non-human or transformed bone cells (Centrella et al. 1995, 1988, Iimura et al. 1994). Interaction with matrix collagen was shown to be able to reduce the number of cell-surface receptors and actions of TGF- $\beta$ in murine osteoblastic cells (Takeuchi et al. 1996). Furthermore, betaglycan (T $\beta R-I I I)$, which is seemingly not involved in the regular signal transduction pathway, may modulate TGF- $\beta$-induced responses of mesenchymal cells. Accordingly, there is circumstantial evidence that betaglycan in its soluble form might act as a potential antagonist of TGF- $\beta$, whereas in a membraneassociated form it may enhance the binding of TGF- $\beta$ to the signalling receptors I and II (López-Casillas et al. 1994, Massagué et al. 1994). Other regulatory mechanisms are suggested by a set of experiments which show that a rapid turnover of T $\beta$ Rs -I, -II and -III by ligand-independent and ligand-dependent mechanisms are observed in nonhuman, fetal cell culture systems (Centrella et al. 1996). The present study was undertaken to investigate the influence of TGF- $\beta 1$ on the cell-surface expression of its own receptors in cultured human osteoblast-like cells from adult donors. Special emphasis was placed upon T $\beta R$-II, as it is important for the initial binding of TGF- $\beta$ and triggers the cytoplasmic signalling cascade associated with T $\beta R-I$.

\section{Materials and Methods}

\section{Human bone cell culture}

Human osteoblast-like cells (hOBs) were isolated from the trabecular bone of adult femoral head samples obtained by informed consent during routine hip replacement surgery, as described previously (Seitzer et al. 1995). Briefly, fragments were seeded as explants into tissue culture flasks and cultured at $37^{\circ} \mathrm{C}$ in a humidified atmosphere of $95 \%$ air and $5 \% \mathrm{CO}_{2}$. The cells reached confluency after 3-4 weeks. Culture medium was Dulbecco's modified Eagle's medium supplemented with $50 \mathrm{mg} / \mathrm{ml}$ L-ascorbate, $100 \mathrm{U} / \mathrm{ml}$ penicillin, $100 \mathrm{mg} / \mathrm{ml}$ streptomycin, $2 \mathrm{mM}$ L-glutamine and $10 \%$ fetal calf serum (FCS). Cells were defined as osteoblast-like cells by the determination of osteoblast markers: cytochemical staining for alkline phosphatase (ALP) could be demonstrated on $60-80 \%$ of the cells and was negative on control fibroblasts; the ALP activity was stimulated $3 \cdot 7$-fold by 1,25 dihydroxy vitamin $\mathrm{D}_{3}$ $(50 \mathrm{nM})$, and the osteocalcin concentration increased 18-fold under the same conditions; incubation with $90 \mathrm{nM}$ human parathyroid hormone(1-34) stimulated cAMP fourfold; in vitro mineralization could be demonstrated (Seitzer et al. 1995). In addition, the human osteosarcoma-derived osteoblastic cell line, MG63, was used for the crosslinking experiments.

\section{Incubation conditions}

In order to analyse the influence of TGF- $\beta 1$ on cellsurface binding of ${ }^{125}$ I-TGF- $\beta 1$ to specific receptors on $\mathrm{hOB}$, three independent experiments with double determinations each were perfomed in different cell populations by adding TGF- $\beta 1$ for $0 \cdot 5,2,4,8,18$ and $24 \mathrm{~h}$ in three different concentrations (0, 40 and $200 \mathrm{pM})$ before the analyses described below. Before the incubation medium was removed, cells were placed on ice to preserve the effects of TGF- $\beta 1$. Alternatively, TGF- $\beta 1$ was removed after an 18-h preincubation in order to investigate receptor recovery in the absence of the ligand. Control experiments using ${ }^{125}$ I-TGF- $\beta 1$ (40 pM) instead of native TGF- $\beta 1$ were perfomed according to the procedure of Massagué \& Like (1985), to rule out any residual occupancy of cellular receptors for TGF- $\beta$ after the first incubation.

\section{Binding assay}

Binding studies were performed according to the technique of Massagué (1985), using ${ }^{125}$ I-labelled TGF- $\beta 1$ obtained in a lyophylized form (Amersham-Buchler, Braunschweig, FRG), and reconstituted in $100 \mathrm{ml} 4 \mathrm{mM}$ $\mathrm{HCl}, 2 \mathrm{mg} / \mathrm{ml}$ BSA and diluted with binding buffer $(128 \mathrm{mM} \mathrm{NaCl}, 5 \mathrm{mM} \mathrm{KCl}, 5 \mathrm{mM} \mathrm{MgSO}, 1.2 \mathrm{mM}$ $\mathrm{CaCl}_{2}, 50 \mathrm{mM}$ HEPES, $\mathrm{pH} 7 \cdot 5,2 \mathrm{mg} / \mathrm{ml}$ BSA) to a $100 \mathrm{pM}$ stock solution. Suitable aliquots were stored at $-80{ }^{\circ} \mathrm{C}$ until required for use. All cell culture dishes and tubes used for analysing TGF- $\beta 1$ binding were of polypropylene or siliconized material.

To prepare cultures for binding studies, cells were seeded into six-well dishes and grown for $24 \mathrm{~h}$. The medium was removed and confluent monolayer cultures of cells were washed with $1 \mathrm{ml}$ binding buffer and allowed to equilibrate with binding buffer at $4{ }^{\circ} \mathrm{C}$. After $30 \mathrm{~min}$, the buffer solution was aspirated from the plates on ice. Ice-cold binding buffer and ${ }^{125} \mathrm{I}-\mathrm{TGF}-\beta 1$ were added to different concentrations of ${ }^{125}$ I-TGF- $\beta 1$ in the range $1 \cdot 25-30 \mathrm{pM}$ and to a final volume of $2 \mathrm{ml}$. The cells were then incubated at $4{ }^{\circ} \mathrm{C}$ on a platform oscillating at 120 r.p.m. for $3.5 \mathrm{~h}$. In addition, a 50 -fold excess of unlabelled TGF- $\beta 1$ added immediately before incubation with ${ }^{125}$ I-TGF- $\beta$ was used to determine the amount of ${ }^{125}$ I-labelled TGF- $\beta$ bound non-specifically to the surface of cells or plastic dishes. Binding buffer without ${ }^{125}$ I-TGF- $\beta 1$ was added to those six-well plates that were used in parallel for cell counting using a Neubauer counting chamber.

To quantify free ligand concentrations, the buffer was removed from the wells cooled on ice and the wells were rinsed twice with $1 \mathrm{ml}$ ice-cold binding buffer. The combined fractions were analysed for free radioactivity in a gamma counter. To quantify bound ligand, the wells were rinsed for three additional times, then $2 \mathrm{ml}$ 
solubilization buffer I (25 mM HEPES, 1\% (v/v) Triton $\mathrm{X}-100,10 \%$ (v/v) glycerol, $\mathrm{pH} 7 \cdot 5,1 \mathrm{mg} / \mathrm{ml} \mathrm{BSA}$ ) were added and incubated for $40 \mathrm{~min}$ at $4{ }^{\circ} \mathrm{C}$ on the platform. The buffer was removed, the wells were rinsed twice and the combined fractions were analysed in a gamma counter. The difference between c.p.m. bound in the presence and absence of excess unlabelled TGF- $\beta$ was considered to represent specific binding. Saturation analysis was carried out according to Scatchard (1949).

\section{Crosslinking experiments}

The crosslinking experiments were performed according to Massagué (1985). Cell monolayers were treated according to the procedure described for the binding studies. After the equilibration step, cells were incubated with $20 \mathrm{pM}{ }^{125}$ I-labelled TGF- $\beta 1$ in binding buffer at $4{ }^{\circ} \mathrm{C}$ on a platform oscillating at $2 \mathrm{~Hz}$ for $3.5 \mathrm{~h}$. Next, wells were washed five times with binding buffer lacking BSA and then covered with $2 \mathrm{ml}$ of this buffer, into which $10 \mathrm{ml}$ freshly prepared $27 \mathrm{mM}$ disuccinimidylsuberate (DSS) solution (Pierce, Rockford, USA) in dimethyl sulphoxide were dispensed directly, during swirling. The dishes were left agitating at $4{ }^{\circ} \mathrm{C}$ for $15 \mathrm{~min}$. Cells were briefly rinsed with ice-cold detachment buffer $(250 \mathrm{mM}$ saccharose, $1 \mathrm{mM}$ EDTA, $10 \mathrm{mM}$ Tris-HCl, $\mathrm{pH} 7 \cdot 4$ supplemented with an inhibitor cocktail, Boehringer Mannheim, Mannheim, Germany) and then scraped off in the presence of $0.5 \mathrm{ml}$ detachment buffer, using a disposable scraper. The wells were rinsed with a second aliquot of detachment buffer. Cells were pelleted by centrifugation at $20000 \mathrm{~g}$ for $2 \mathrm{~min}$ at $4{ }^{\circ} \mathrm{C}$ in 2 -ml microcentrifuge tubes and the supernatant was removed. Cell pellets were resuspended by repeated pipetting with $60 \mathrm{ml}$ solubilization buffer II $(125 \mathrm{mM} \mathrm{NaCl}, 1 \mathrm{mM}$ EDTA, $10 \mathrm{mM}$ Tris- $\mathrm{HCl}, \mathrm{pH} 7 \cdot 0,1 \%(\mathrm{v} / \mathrm{v})$ Triton X-100, supplemented with an inhibitor cocktail) and incubated for $40 \mathrm{~min}$ at $4{ }^{\circ} \mathrm{C}$ with end-over-end mixing. Insoluble cell debris was removed by centrifugation at $20000 \mathrm{~g}$ at $4{ }^{\circ} \mathrm{C}$ for $15 \mathrm{~min}$. The supernatant was mixed with an equal volume of electrophoresis sample buffer and heated at $90{ }^{\circ} \mathrm{C}$ for $2 \mathrm{~min}$. Samples were then subjected to SDS-PAGE on $10 \%$ polyacrylamide gels. Gels were fixed and dried, followed by autoradiography for up to 30 days using an intensifying screen (Reflection Autoradiography Film and Screen, NEN, Boston, MA, USA).

\section{Immunoblots for TRR-II and betaglycan}

Cell monolayers grown to confluency overnight were incubated with $200 \mathrm{nM}$ TGF- $\beta 1$ or vehicle for $24 \mathrm{~h}$ and $48 \mathrm{~h}$. Medium was then removed from cells on ice. Cell collection and SDS-PAGE were performed according to the crosslinking protocol. Before SDS-PAGE, the protein content in each sample was determined according to Lowry et al. (1951) (Lowry, DC Protein Assay kit,
Bio-Rad, Hercules, CA, USA). Equal amounts of protein for each sample were mixed with 1 vol Laemmli sample buffer containing $1 \% \beta$-mercaptoethanol, heated at $95^{\circ} \mathrm{C}$ for $2 \mathrm{~min}$ and loaded onto a $10 \%$ polyacrylamide gel, followed by electrotransfer to a $0 \cdot 45-\mathrm{mm}$ nitrocellulose membrane (Bio-Rad). After washing for $5 \mathrm{~min}$ in $50 \mathrm{mM}$ $\mathrm{NaCl}, 10 \mathrm{mM}$ Tris-HCl, pH 7•4, 1\% Tween 20 (TBST), the membrane was incubated in blocking buffer $(5 \%$ BSA in TBST) with gentle agitation overnight at $4{ }^{\circ} \mathrm{C}$. The primary antibody (R\&D Systems, Wiesbaden, FRG) was added in a concentration of $25 \mathrm{ng} / \mathrm{ml}$ in blocking buffer for $1 \mathrm{~h}$, with agitation, at room temperature, followed by washing for $3 \times 5 \mathrm{~min}$ and incubation with the second antibody (donkey anti-goat, conjugated to alkaline phosphatase; Dianova, Hamburg, FRG) in a concentration of $600 \mathrm{ng} / \mathrm{ml}$. After washing, the membrane was equilibrated in substrate buffer $(100 \mathrm{mM} \mathrm{NaCl}, 5 \mathrm{mM}$ $\mathrm{MgCl}_{2}, 100 \mathrm{mM}$ Tris-HCl, pH 9.5). Blots were then developed in $20 \mathrm{ml}$ substrate buffer containing $132 \mathrm{ml}$ nitro blue tetrazolium (NBT) stock solution $(50 \mathrm{mg} / \mathrm{ml}$ NBT in 70\% dimethyl-formamide (DMF)) and $66 \mathrm{ml}$ 5-bromo-4-chloro-3-indolyl phosphate (BCIP) stock solution $(50 \mathrm{mg} / \mathrm{ml} \mathrm{BCIP}$ in $100 \%$ DMF) until the desired degree of staining has been achieved. In an additional experiment, the pellet was analysed for immunoreactivity for both T $\beta$ R-II and T $\beta$ R-III. For this purpose, the pellet was solubilized in $2.5 \% \mathrm{SDS}$ and heated at $95^{\circ} \mathrm{C}$ for $2 \mathrm{~min}$ before the immunoblotting procedure described above.

\section{Analysis of TRR-II gene expression by reverse transcription (RT)-PCR}

For semi-quantitative analysis, T $\beta \mathrm{R}-\mathrm{II}$ gene expression was studied by RT-PCR in relation to expression of the housekeeping gene, glyceraldehyde-3-phosphate dehydrogenase (GAPDH), used as a coamplified internal standard (Kruse et al. 1998). Total RNA from human osteoblast-like cells was isolated using the RNeasy kit (Qiagen, Hilden, FRG). Samples of $2 \mathrm{mg}$ were reversetranscribed and amplified using sequence-specific oligonucleotide primers for both the T $\beta \mathrm{R}-\mathrm{II}$ and the GAPDH gene included in the same reactions. To exclude contamination of genomic DNA as a source for amplified products, each reaction was also carried out without reverse transcriptase. Sequences of the antisense and sense primers were: GAPDH: 5'-GCA ACT GTG AGG AGG GGA GAT TCA G-3', 5'-CCG CAT CTT CTT TTG CGT CGC-3'; TßR-II: 5'-GCC TGC CCC ATA AGA GCT ATT TGG TAG TG-3', 5'-GAA GAA CGA CCT AAC CTG CTG CCT- $3^{\prime}$.

PCR was performed on $1 / 20$ of the reversetranscription reaction using Vent-Polymerase (Biolabs, Schwalbach, FRG) and following the protocols supplied by the manufacturers (each cycle consisted of $40 \mathrm{~s}$ of denaturation at $95^{\circ} \mathrm{C}, 40 \mathrm{~s}$ annealing at $56{ }^{\circ} \mathrm{C}$, and $60 \mathrm{~s}$ of elongation at $72{ }^{\circ} \mathrm{C}$ ). Amplification of both GAPDH and 


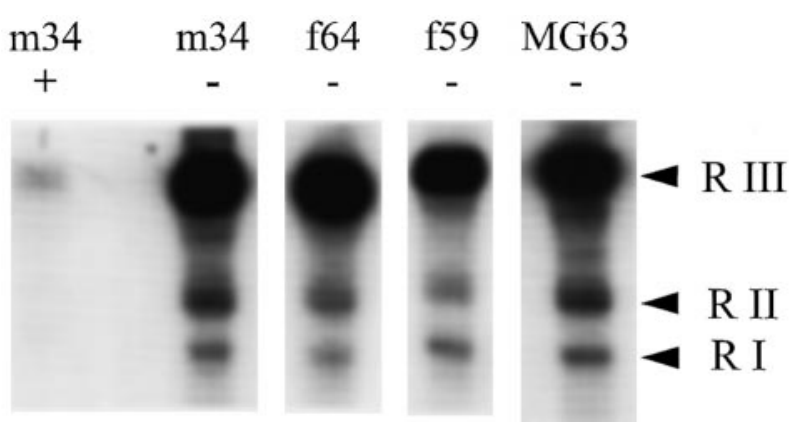

Figure 1 Cell-surface expression of T $\beta$ Rs on representative human osteoblast-like cells from adult donors and on cells of the osteosarcoma-derived osteoblastic cell line, MG63. Analysis was performed by crosslinking with DSS after binding of ${ }^{125}$ I-TGF- $\beta 1$ (-). TRRs -I (RI), -II (RII) and -III (RIII) (betaglycan) are seen at approximately 80,100 and $180 \mathrm{kDa}$ respectively. Specificity of binding was demonstrated by inhibition of labelling after preincubation (+) with an excess of unlabelled TGF- $\beta 1 . m 34, f 64$ and $\mathrm{f59}$ denote osteoblast populations from male $(\mathrm{m})$ and female (f) donors 34, 64 and 59 years of age respectively.

T $\beta$ R-II was found to be in the linear range when 30 cycles of amplification were used.

\section{Statistics}

Calculation of means and standard deviations presented in Fig. 4 was performed on data derived from four separate experiments with double determination each. Statistical analysis was carried out using ANOVA. Statistical significance was considered for $P<0 \cdot 05$.

\section{Results}

\section{Cell-surface expression of TGF- $\beta$-receptors}

The cell-surface expression of T $\beta$ Rs on human osteoblastlike cells as revealed by affinity crosslinking studies using ${ }^{125}$ I-TGF $\beta$ is shown in Fig. 1 . T $\beta$ Rs - I, -II and -III (betaglycan) were abundantly present on cultured human osteoblast-like cells as visualized by electrophoretic separation of the receptor-ligand complexes, showing the expected bands migrating at approximately 80, 100 and $280 \mathrm{kDa}$, respectively, which is in good agreement with data published by other authors (Attisano et al. 1994). The specificity of the binding was demonstrated by an inhibition of labelling after preincubation with an excess of unlabelled TGF- $\beta 1$. When a total of 20 different human osteoblast populations or transformed osteoblastic cells (MG63) was analysed, virtually the same banding pattern was seen for all cells (representative findings are shown in Fig. 1). In agreement with the data obtained by the binding studies and the immunoblotting described below, preincubation with unlabelled TGF- $\beta 1$ also revealed

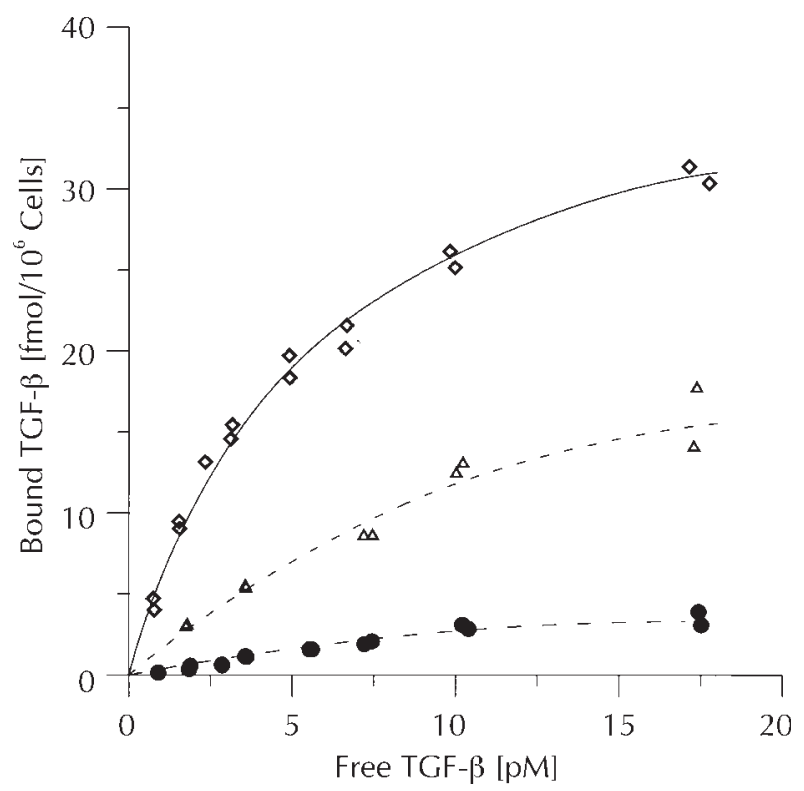

Figure 2 Specific binding curves of ${ }^{125}$ I-TGF- $\beta 1$ on human osteoblast-like cells after preincubation with different concentrations $(40 \mathrm{pM}(\triangle)$ and $200 \mathrm{pM}(\bullet))$ of unlabelled TGF- $\beta 1 . \diamond$, Control values without TGF- $\beta 1$ preincubation.

a decrease in all three receptor types in the affinity crosslinking studies (data not shown).

\section{Specific binding of ${ }^{125} I-T G F-\beta$}

To demonstrate the presence of receptors specific for TGF- $\beta$ on human osteoblast-like cells, binding of ${ }^{125}$ I-TGF- $\beta 1$ was analysed and specific binding curves were obtained by subtraction of unspecific binding from total binding. Preincubation with $40 \mathrm{pM}$ and $200 \mathrm{pM}$ unlabelled TGF- $\beta 1$ for $18 \mathrm{~h}$ resulted in a marked and dose-dependent reduction of specific binding of ${ }^{125}$ I-TGF- $\beta$ (Fig. 2). Different preincubation times with unlabelled TGF- $\beta 1$ (200 pM) revealed a time-dependent significant reduction of specific binding of ${ }^{125}$ I-TGF- $\beta$. Binding was greater after 30 min than after $2 \mathrm{~h}$ and $4 \mathrm{~h}$ preincubation, and was least after $18 \mathrm{~h}$ preincubation (Fig. 3a). Further analysis of the binding data showed that this represented significant reductions $(53,84,90$ and $95 \%$ compared with control) in the presence of cell-surface receptors able to bind TGF- $\beta 1$ after ligand preincubation for $0.5,2,4$ and $18 \mathrm{~h}$, respectively, while the receptor affinity did not change significantly under the different preincubation conditions (Fig. 4). No recovery of receptor binding capacity was observed for up to $18 \mathrm{~h}$ in the presence of the ligand (Fig. 3a). Also, there was no evidence for receptor recovery for up to $24 \mathrm{~h}$ after TGF- $\beta 1$ had been removed (Fig. $3 b$ ).

Control experiments using ${ }^{125}$ I-TGF- $\beta$ instead of unlabelled TGF- $\beta$ in the first incubation also showed a 


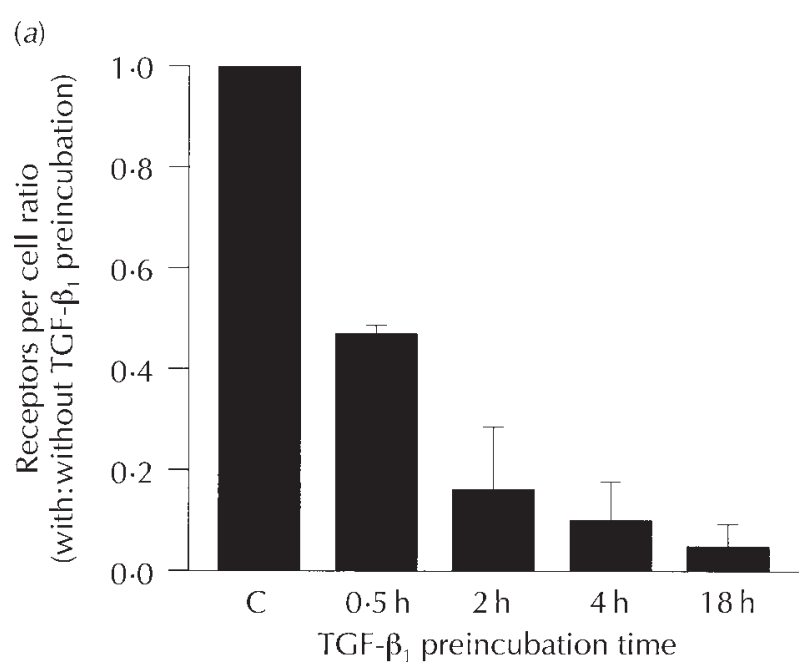

(b)

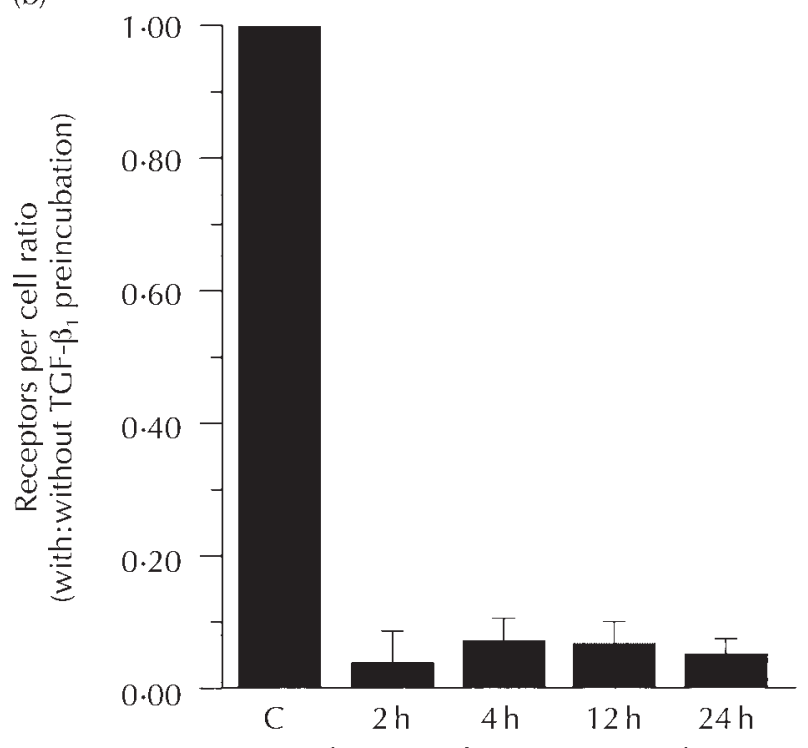

Time after stop of TGF- $\beta_{1}$ preincubation

Figure 3 (a) Number of T $\beta$ Rs per cell and their significant decrease after preincubation with unlabelled TGF- $\beta 1$ for different durations $(0,0 \cdot 5,2,4$ and $18 \mathrm{~h})$. (b) Number of T $\beta$ Rs per cell after an 18-h preincubation with TGF- $\beta 1$. Different time points after the removal of TGF- $\beta 1$ are shown $(0,4,12$ and $24 \mathrm{~h})$. Values in both (a) and (b) are expressed as the ratio of receptor number (mean \pm S.D. of four separate experiments) with and without TGF- $\beta$ preincubation and normalized to the value observed without TGF- $\beta 1$ preincubation $(C$, control).

reduction of specific ligand binding and thus indicated that no residual occupancy of cellular receptors was present.

\section{Immunoblotting analyses}

To analyse the influence of preincubation with TGF- $\beta$ on the cell-surface expression of individual $T \beta R$ proteins,

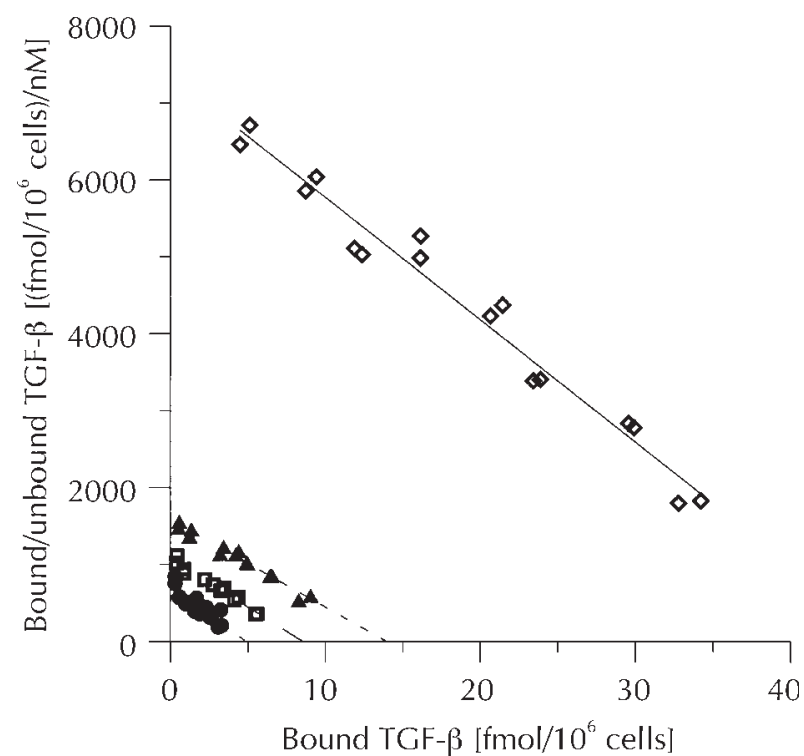

Figure 4 Scatchard analysis of the binding data obtained by the specific binding of ${ }^{125}$ I-TGF- $\beta 1$ on human osteoblast-like cells after preincubation with unlabelled TGF- $\beta 1$ for $2(\boldsymbol{\Delta}), 4(\square)$ and $18(\bullet)$ h. $\diamond$, Control values without TGF- $\beta 1$ preincubation. There is decreased specific binding capacity (derived from the intercept on the abscissa) with TGF- $\beta 1$ preincubation, without change in affinity (slope).

immunoblotting analyses were carried out under denaturing conditions, which completely disrupt any ligandreceptor binding. Because T $\beta \mathrm{R}-\mathrm{II}$ can bind TGF- $\beta$ independently of T $\beta R-I$, and binding to T $\beta R-I I$ is the first step in TGF- $\beta$ signalling (Heldin et al. 1997), immunoblotting was performed with antibodies against T $\beta \mathrm{R}-\mathrm{II}$. The semi-quantitative analysis showed an almost complete disappearance of immunoreactivity for T $\beta \mathrm{R}-\mathrm{II}$ after a 24-h and 48-h preincubation with 200 pM TGF- $\beta 1$ (Fig. $5 a$; data shown are for $24 \mathrm{~h}$ ), under both reducing and non-reducing conditions. In addition, immunoblotting with specific antibodies against betaglycan was also performed, because betaglycan (T $\beta R$-III) seems to have a role in presenting TGF- $\beta$ to T $\beta$ R-II (López-Casillas et al. 1994). As shown in Fig. $5 a$, the T $\beta$ R-III core protein (López-Casillas et al. 1994) was almost undetectable by specific antibodies after preincubation (for 24 or $48 \mathrm{~h}$; data shown are for $48 \mathrm{~h}$ ) with TGF- $\beta 1$ ( $40 \mathrm{pM})$. Analysis of the solubilized pellet failed to show any immunoreactivity for either T $\beta \mathrm{R}-\mathrm{II}$ or T $\beta \mathrm{R}-\mathrm{III}$, and gave the same results with or without TGF- $\beta$ preincubation (Fig. $5 b$ ). It therefore appears unlikely that the receptors had been moved to an insoluble membrane compartment in the course of the experiments.

\section{Expression of TRR-II $m R N A$}

To investigate the influence of a $24-\mathrm{h}$ preincubation with TGF- $\beta 1$ on the expression of T $\beta$ R-II mRNA, 
(a)

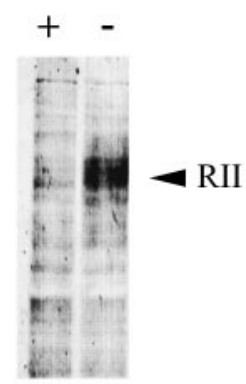

(b)

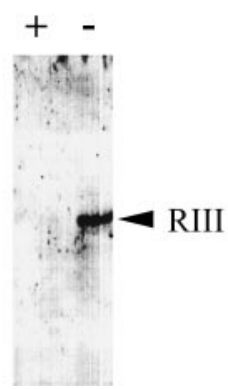

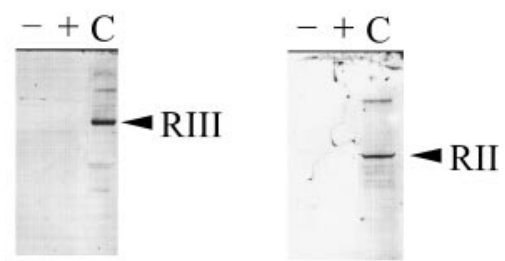

Figure 5 Immunoblotting analyses of T $\beta$ Rs-II and -III. (a) Specific bands at a molecular weight of approximately 80 and $110 \mathrm{kDa}$ (core protein), respectively, on human osteoblast-like cells with (+) or without (-) TGF- $\beta 1$ preincubation for $24 \mathrm{~h}(\mathrm{~T} \beta \mathrm{R}-\mathrm{II})$ and $48 \mathrm{~h}$ (T $\beta$ R-III). (b) Analyses of the solubilized pellet with (+) and without (-) TGF- $\beta$ preincubation, and control (C).

semi-quantitative RT-PCR was performed using GAPDH mRNA levels as internal standard. As shown in Fig. 6, there was no significant effect of TGF- $\beta 1$ on the expression of T $\beta R$-II mRNA. The marked changes in receptor binding profiles and receptor immunoreactivity observed after incubation with TGF- $\beta 1$ therefore apparently were not paralleled by alterations in the T $\beta$ R-II transcript levels.

\section{Discussion}

It is generally accepted that TGF- $\beta$ may have a pivotal role in co-ordinating bone deposition and resorption (Bonewald \& Dallas 1994, Centrella et al. 1994) and may therefore represent a candidate factor for coupling both processes. In addition, there is increasing evidence that TGF- $\beta$ exerts a critical local function in the skeleton with regard to augmenting or maintaining bone mass and its structural integrity. In this respect, a net bone loss or bone gain has been shown to be selectively induced by overexpression of TGF- $\beta$ or inhibition of $T \beta R$ function, respectively (Erlebacher \& Derynck 1996, Filvaroff et al. 1997). The most pronounced effect of TGF- $\beta$ is the

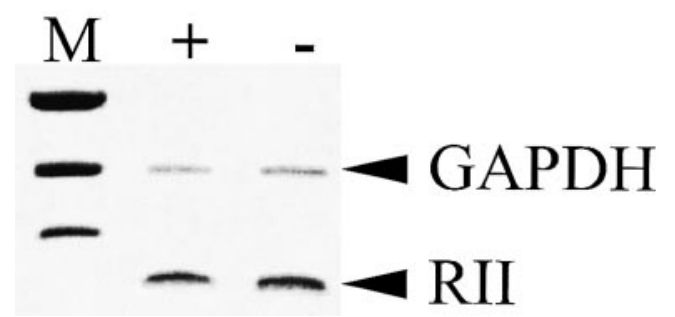

Figure 6 T $\beta R$-II (RII) mRNA analysed by RT-PCR. There was no change in the RII:GAPDH mRNA ratio after a 24-h incubation with TGF- $\beta 1(+)$ compared with control (-). M, Marker. stimulation of the synthesis of bone matrix proteins, including collagen I, proteoglycans and fibronectin, and its potential to influence the functional properties of the collagenous bone matrix (Takeuchi et al. 1996, Seitzer et al. 1995). In contrast, there is convincing evidence that TGF- $\beta$ inhibits the final mineralization process during bone maturation (Harris et al. 1994, Takeuchi et al. 1996), which provides further support for a tight regulation of its action during tissue formation and remodelling of bone. To date, little is known about how the TGF- $\beta$ responsiveness of bone-forming cells, which possess three types of T $\beta$ Rs, might be regulated in the human skeletal system. Some, but not all, studies using rodent or transformed mesenchymal cells have reported a downregulation of receptors for TGF- $\beta$ by the ligand itself (Massagué \& Like 1985, Wakefield et al. 1987, Centrella et al. 1996). The present study on adult human osteoblast-like cells provides additional evidence that TGF- $\beta 1$ reduces the number of specific T $\beta$ Rs per cell exposed on the cell surface, in a dose- and time-dependent manner. Any residual occupancy of cellular receptors resulting from the preincubation was excluded by control experiments using ${ }^{125}$ I-labelled TGF- $\beta 1$ instead of unlabelled TGF- $\beta 1$ in the first incubation, which also resulted in a decreased total binding of ${ }^{125}$ I-TGF- $\beta 1$ after the second incubation. In the case of residual binding from the first incubation, one would expect identical or higher labelling values (Massagué \& Like 1985). Furthermore, there was a dose-dependent effect of ligand binding even after exposure times longer and with ligand concentrations greater than necessary for a complete saturation of all receptors. Finally, the immunoblotting experiments with antibodies against T $\beta$ Rs -II and -III were performed under conditions that completely disrupt any receptorligand binding, and they also revealed a drastically reduced amount of receptor protein after TGF- $\beta$ preincubation. 
The reduction of the cell-surface binding capacity was about $84 \%$ and $90 \%$ after 2 and 4 h of preincubation with $5 \mathrm{ng} / \mathrm{ml}$ TGF- $\beta$, respectively, and approached 100\% after $18 \mathrm{~h}$. In addition, the effect of preincubation with TGF- $\beta$ showed a clear dose-dependency. Earlier studies using fetal rat fibroblasts or rodent cell lines failed to show a marked receptor downregulation after a 2-h treatment with unlabelled TGF- $\beta$ (Massagué \& Like 1985, Wakefield et al. 1987). In contrast, our data are mostly in accordance with the results of a recent study by Centrella et al. (1996) on fetal rat calvarial cells. However, in that study a return of the full cell-surface binding capacity after $24-48 \mathrm{~h}$ at lower concentrations of TGF- $\beta$ was reported, and a persistent downregulation was observed after exposure to $400 \mathrm{pM}$ TGF- $\beta$. Our data obtained by complete binding studies would suggest that, in non-fetal human osteoblast-like cells, there seems to be a near total $(>90 \%)$ ligand-induced downregulation of T $\beta$ Rs -II and -III at a concentration of $200 \mathrm{pM}$ and greater after an exposure time of $4 \mathrm{~h}$ and longer, without any evidence for receptor recovery within the first $24 \mathrm{~h}$ as shown by immunoblotting. Furthermore, binding studies revealed that no receptor recovery was present for up to $24 \mathrm{~h}$ after the exposure to TGF- $\beta$ had been stopped.

The ligand-induced downregulation of receptors for TGF- $\beta$ could be biologically significant with regard to the changing role of TGF- $\beta$ during osteoblastic differentiation. The abundance of TGF- $\beta$ in bone tissue may exceed the amount needed for osteoblast function during certain stages of skeletal organogenesis. As TGF- $\beta$ strongly inhibits the expression of ALP and osteocalcin and the formation of mineralized bone nodules (Wrana et al. 1988, Noda 1989, Harris et al. 1994), a tight regulation of the actions of TGF- $\beta$ is important in later stages of bone tissue formation. A differentiation-associated downregulation of $T \beta R$ s mediated by interaction between murine osteoblasts and matrix collagen has been reported, and osteoblastic differentiation of multipotential mesenchymal cells induced by retinoic acid was shown to reduce the cell surface binding of TGF- $\beta$ (Gazit et al. 1993, Takeuchi et al. 1996). In contrast, an upregulation of type I receptors for bone morphogenetic proteins, which also belong to the TGF- $\beta$ superfamily but, in contrast to TGF- $\beta$, have a stimulatory effect on mineralization, has been shown to occur during bone formation (Ishidou et al. 1995). The data obtained in our study on human osteoblasts suggest that TGF- $\beta 1$, which is present in high concentrations in the osteoblastic microenvironment and released from accumulated matrix during bone resorption, is able to reduce the number of its own cell-surface receptors. In contrast, no significant effect on receptor affinity was observed. Thus one might speculate that, during the late steps of osteosynthesis such as the mineralization phase, the inhibitory effect of high concentrations of TGF- $\beta 1$ during bone remodelling could be suppressed, as lower levels of T $\beta$ Rs would enable mineralization in regions where the organic bone matrix is already sufficiently formed. The concentrations of active TGF- $\beta 1$ applied in our in vitro incubation experiments are unlikely to be supraphysiological, and are even lower than those reported recently for human bone tissue (Nicolas et al. 1994, Pfeilschifter et al. 1998). However, it cannot completely be ruled out that an activation of latent TGF- $\beta 1$ stored in the matrix occurred during the extraction procedure, which might have resulted in higher concentrations of detectable TGF- $\beta 1$ when only active TGF- $\beta 1$ was measured.

The mechanism by which TGF- $\beta$-binding receptors are decreased appears not to be based on transcriptional events, because the amount of T $\beta$ R-II mRNA was not significantly decreased by TGF- $\beta$ in our study. Rather, on the basis of results of the semi-quantitative RT-PCR, one may speculate that the decrease is due to posttranscriptional effects, for example changes in the intracellular trafficking of receptor proteins. Both endocytotic and degradational downregulation of receptors have been described as general mechanisms, depending on whether an increased internalization or degradation is induced by the ligand (Zigmond et al. 1982, Wiley et al. 1985). Similar mechanisms have been suggested regarding the collageninduced downregulation of T $\beta R$ s, which likewise was not paralleled by a reduction in the abundance of the transcript for T $\beta$ R-II (Takeuchi et al. 1996). An additional possibility is that intracellular protein phosphorylation influences the binding capacity of the cell-surface receptors. Treatment with protein kinase inhibitors has recently been shown to alter TGF- $\beta$ binding (Centrella et al. 1996). However, while an altered accessibility of labelled ${ }^{125}$ I-TGF- $\beta 1$ to its receptors cannot be ruled out, our results obtained by immunoblotting of T $\beta R$ s -II and -III and performed after cell lysis at least also suggest a reduced amount of T $\beta \mathrm{R}-\mathrm{II}$ and $\mathrm{T} \beta \mathrm{R}-\mathrm{III}$ protein induced by preincubation with TGF- $\beta 1$, without any evidence for an altered receptor affinity. Further investigation is required on the precise mechanisms of ligand-induced downregulation of receptors for TGF- $\beta$ on human osteoblast-like cells.

\section{Acknowledgements}

We would like to thank Mrs Katja Thiele for expert technical assistance. We are grateful for the co-operation of the Orthopaedic Department of the Medizinische Universität zu Lübeck in obtaining bone samples for the isolation of human osteoblast-like cells. We also thank Mrs Dagmar Wilkom for providing the GAPDH primers. This study was accomplished with the support of Deutsche Forschungsgemeinschaft-Sonderforschungsbereich 367 (SFB 367-A1). We also thank Dr E Brandt, F Z Borstel and Dr C Kruse, Lübeck, for critical reading of the manuscript. 


\section{References}

Attisano L, Wrana JL, Lopez-Casillas F \& Massagué J 1994 TGF- $\beta$ receptors and actions. Biochimica et Biophysica Acta 1222 71-80.

Bonewald LF \& Dallas SL 1994 Role of active and latent transforming growth factor b in bone formation. Journal of Cellular Biochemistry $\mathbf{5 5}$ 350-357.

Centrella M, McCarthy TL \& Canalis E 1988 PTH modulates TGF- $\beta$ activity and binding in osteoblast-enriched cultures from fetal rat parietal bone. Proceedings of the National Academy of Sciences of the USA 85 5889-5893.

Centrella M, Casinghino S, Ignotz R \& McCarthy TL 1992 Multiple regulatory effects by TGF- $\beta$ on type I collagen levels in osteoblastenriched cultures from fetal rat bone. Endocrinology 131 2863-2872.

Centrella M, Horowitz MC, Wozney JM \& McCarthy TL 1994 TGF- $\beta$ gene family members and bone. Endocrine Reviews 15 27-39.

Centrella M, Casinghino S, Kim J, Pham T, Rosen V, Wozney J \& McCarthy TL 1995 Independent changes in type I and type II receptors for TGF- $\beta$ induced by BMP-2 parallel expression of the osteoblast phenotype. Molecular and Cellular Biology 15 3273-3281.

Centrella M, Ji C, Casinghino S \& McCarthy TL 1996 Rapid flux in TGF- $\beta$ receptors on bone cells. Journal of Biological Chemistry 271 18616-18622.

Erlebacher A \& Derynck R 1996 Increased expression of TGF- $\beta 2$ in osteoblasts results in an osteoporosis-like phenotype. Journal of Cellular Biology 132 195-210.

Filvaroff EH, Erlebacher A, Ye JO, Gitelmann SE, Lotz JC, Heilmann MR \& Derynck R 1997 Increased trabecular bone in transgenic mice expressing a truncated, dominant-negative type II TGF- $\beta$ receptor in osteoblasts. Journal of Bone and Mineral Research 12 S118.

Franzén P, tenDijke P, Ichijo H, Yamashita H, Schulz P, Heldin $\mathrm{CH}$ \& Miyazono K 1993 Cloning of the TGFb type I receptor that forms a heteromeric complex with the TGFb type II receptor. Cell 75 681-692.

Gazit D, Ebner R, Kahn AJ \& Derynck R 1993 Modulation of expression and cell surface binding of members of the TGF- $\beta$ superfamily during retinoic acid-induced osteoblastic differentiation of multipotential mesenchymal cells. Molecular Endocrinology 7 189-198.

Harris SE, Bonewald LF, Harris MA, Sabatini M, Dallas S, Feng JQ, Ghosh-Choudhury N, Wozney J \& Mundy GR 1994 Effects of TGF- $\beta$ on bone nodule formation and expression of BMP-2, osteocalcin, osteopontin, alkaline phosphatase, and type I collagen mRNA in long-term cultures of fetal rat calvarial osteoblasts. Journal of Bone and Mineral Research 9 855-863.

Heldin CH, Miyazono K \& tenDilke P 1997 TGF- $\beta$ signalling from cell membrane to nucleus through SMAD proteins. Nature $\mathbf{3 9 0}$ 465-471.

Iimura T, Oida S, Ichijo H, Goseki M, Maruoka Y, Takeda K \& Sasaki S 1994 Modulation of responses to TGF- $\beta$ by 1,25 dihydroxyvitamin D3 in MG-63 osteoblastic cells. Biochemical and Biophysical Research Communications 204 918-923.

Ishidou Y, Kitajima I, Obama H, Maruyama I, Murata F, Imamura T, Yamada N, tenDijke P, Miyazono K \& Sakou T 1995 Enhanced expression of type I receptors for bone morphogenetic proteins during bone formation. Journal of Bone and Mineral Research $\mathbf{1 0}$ 1652-1659.

Kruse C, Emmrich J, Rumperl E, Klinger MH, Grünweller A, Rohwedel J, Krammer HJ, Kühnel W \& Müller PK 1998 Producion of trypsin by cells of the exocrine pancreas is paralleled by the expression of the $\mathrm{KH}$ protein vigilin. Experimental Cell Research 239 111-118.
López-Casillas F, Payne HM, Andres JL \& Massagué J 1994 Betaglycan can act as dual modulator of TGF- $\beta$ access to signaling receptors: mapping of ligand binding and GAG attachment sites. Journal of Cellular Biology 124 557-568.

Lowry OH, Rosebrough NJ, Farr AL \& Randall RJ 1951 Protein measurement with the Folin phenol reagent. Journal of Biological Chemistry 193 265-275.

Massagué J 1985 Identification of receptors for type b transforming growth factor. Methods in Enzymology 146 174-195.

Massagué J \& Like B 1985 Cellular receptors for type b transforming growth factor. Journal of Biological Chemistry $2602636-2645$.

Massagué J, Attisano L \& Wrana J 1994 The TGF- $\beta$ family and its composite receptors. Trends in Cell Biology 4 172-178.

Nicolas V, Prewett A, Bettica P, Mohan S, Finkelman RD, Baylink DJ \& Farley JR. 1994 Age-related decreases in insulin-like growth factor-I and transforming growth factor-beta in femoral cortical bone from both men and women: implications for bone loss with aging. Journal of Clinical Endocrinology and Metabolism 78 1011-1016.

Noda M 1989 Transcriptional regulation of osteocalcin production by TGF- $\beta$ in rat osteoblast-like cells. Endocrinology 124 612-617.

Pfeilschifter J, Diel I, Scheppach B, Bretz A, Krempien R, Erdmann J, Schmid G, Reske N, Bismar H, Seck T, Krempien B \& Ziegler R 1998 Concentration of TGF- $\beta$ in human bone tissue: relationship to age, menopause, bone turnover and bone volume. Journal of Bone and Mineral Research 13 716-730.

Scatchard G 1949 The attraction of proteins for small molecules and ions. Annals of the New York Academy of Sciences 51 660-671.

Seitzer U, Bätge B, Acil Y \& Müller PK 1995 Transforming growth factor $b_{1}$ influences lysyl hydroxylation of collagen $I$ and reduces steady-state levels of lysylhydroxylase mRNA in human osteoblast-like cells. European Journal of Clinical Investigation $\mathbf{2 5}$ 959-966.

Takeuchi Y, Nakayama K \& Matsumoto T 1996 Differentiation and cell surface expression of TGF- $\beta$ receptors are regulated by interaction with matrix collagen in murine osteoblastic cells. Journal of Biological Chemistry 271 3938-3944.

Wakefield LM, Smith DM, Masui T, Harris C \& Sporn MB 1987 Distribution and modulation of the cellular receptor for TGF- $\beta$. Journal of Cellular Biology 105 965-975.

Wiley HS, van Nostrand W, McKinley D \& Cunningham DD 1985 Intracellular processing of epidermal growth factor and its effect on ligand/receptor interactions. Journal of Biological Chemistry 260 5290-5295.

Wraner JL, Maeno M, Hawrylyshyn B, Yao KL, Domenicucci C \& Sodek J 1988 Differential effects of TGF- $\beta$ on the synthesis of extracellular matrix proteins by normal fetal rat calvarial bone cell populations. Journal of Cellular Biology 106 915-924.

Yamashita $\mathrm{H}$, tenDijke P, Franzén P, Miyazono K \& Heldin CH 1994 Formation of hetero-oligomeric complexes of type I and type II receptors for transforming growth factor- $\beta$. Journal of Biological Chemistry $26920172-20178$.

Zigmond SH, Sullivan SJ \& Lauffenberger DA 1982 Kinetic analysis of chemotactic peptide receptor modulation. Journal of Cellular Biology 92 34-43.

Received 20 July 1998

Revised manuscript received 14 December 1998

Accepted 21 January 1999 